\title{
Online determination of levoglucosan in ambient aerosols with particle-into-liquid sampler - high-performance anion-exchange chromatography - mass spectrometry (PILS-HPAEC-MS)
}

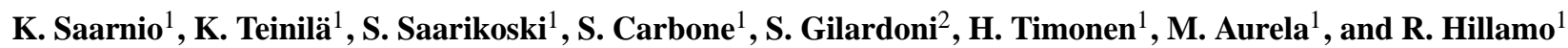 \\ ${ }^{1}$ Finnish Meteorological Institute, Air Quality Research, Helsinki, Finland \\ ${ }^{2}$ National Research Council (CNR), Institute for Atmospheric Sciences and Climate (ISAC), Bologna, Italy \\ Correspondence to: K. Saarnio (karri.saarnio@fmi.fi)
}

Received: 24 May 2013 - Published in Atmos. Meas. Tech. Discuss.: 19 June 2013

Revised: 16 September 2013 - Accepted: 18 September 2013 - Published: 25 October 2013

\begin{abstract}
Biomass burning, such as domestic heating, agricultural, and wild open-land fires, has a significant influence on the atmosphere at the global and, especially, at the local scale. Levoglucosan has been shown to be a good tracer for biomass burning emissions in atmospheric particulate matter, and several analytical techniques have been presented for the determination of levoglucosan from filter samples. In this paper, a novel combination of a particle-into-liquid sampler (PILS) to a high-performance anion-exchange chromatograph (HPAEC) with the detection by a mass spectrometer (MS) is presented for the online analysis of levoglucosan in ambient particles. The PILS-HPAEC-MS technique enables a fast online analysis of levoglucosan from the particulate samples. The method was tested at an urban background station in Helsinki, Finland, in winter 2011. A comparison with simultaneous levoglucosan measurements from filter samples by the HPAEC-MS was performed and it showed a good agreement between the online and offline methods. Additionally, the online levoglucosan data were compared with the biomass burning tracer fragments measured by a high-resolution time-of-flight aerosol mass spectrometer (HR-ToF-AMS). As there were no local biomass burning sources close to the measurement station, online levoglucosan measurements revealed that most of the particles from biomass burning were either regionally distributed or long-range transported in the urban background of Helsinki. The average levoglucosan concentrations were relatively low (average $0.083 \mu \mathrm{g} \mathrm{m}^{-3}$ ) during the measurement campaign. The highest concentration peak measured for levoglucosan
\end{abstract}

$\left(1.4 \mu \mathrm{g} \mathrm{m}^{-3}\right)$ seemed to originate from biomass burning in the Baltic countries, likely in Estonia, that was transported to Helsinki.

\section{Introduction}

Smoke from biomass burning - e.g., open-land fires, slashand-burn agriculture, and residential wood combustion - has a strong influence on the atmospheric particulate matter (PM) concentrations at rural, urban, and regional background sites (e.g., Engling et al., 2006; Saarikoski et al., 2007; Gilardoni et al., 2011; Saarnio et al., 2010a, 2012). Biomass burning can significantly affect global climate, regional air quality, visibility, ecosystems, and human health (e.g., Ramanathan et al., 2001; Seinfeld and Pandis, 2006). Residential heating with wood has been associated with adverse health effects (Boman et al., 2003; Naeher et al., 2007), and it has also been shown that biomass burning emissions contribute to respiratory hospitalizations (Schreuder et al., 2006). Quantification of biomass burning emissions is mandatory to understand the impact of this source on regional and local air quality. High-time-resolution measurements represent added value, since they help to identify biomass burning sources and atmospheric processing.

Molecular markers are commonly used to identify the sources of ambient aerosols and assess their contributions. Anhydrosugars such as monosaccharide anhydrides (MAs: levoglucosan, mannosan, and galactosan, of which 
levoglucosan is typically the most abundant one) are generally used as biomass burning tracers in ambient air particles (e.g., Simoneit, 2002; Yttri et al., 2005; Saarikoski et al., 2008a, b; Niemi et al., 2009; Saarnio et al., 2010a). Levoglucosan is produced specifically from the pyrolysis of plant material (cellulose and hemicelluloses) (Simoneit, 2002) and it is generally used as a tracer for biomass burning because it is considered relatively stable (Fraser and Lakshmanan, 2000). Nevertheless, it has been lately shown that levoglucosan may also be produced to a lesser extent in the pyrolysis of lignite (Fabbri et al., 2009) and that hydroxyl radicals may degrade levoglucosan in atmospheric conditions (Hennigan et al., 2010; Hoffmann et al., 2010).

Several analytical techniques have been presented for the analysis of levoglucosan, e.g., gas chromatography (GC) and diverse liquid-chromatographic (LC) techniques, such as high-performance liquid chromatography (HPLC) and highperformance anion-exchange chromatography (HPAEC) with mass spectrometric (MS) or pulsed amperometric detection (PAD) (e.g., Dye and Yttri, 2005; Engling et al., 2006; Schkolnik and Rudich, 2006; Iinuma et al., 2009; Saarnio et al., 2010b; Piot et al., 2012). The analysis of levoglucosan is traditionally conducted from filter samples with sampling durations from several hours to days. Filter samplings, however, average the levoglucosan concentrations over the sampling period and short-term changes are lost. Hardly any studies present highly time-resolved data of ambient levoglucosan concentrations. That kind of data can be useful to detect diurnal changes and to separate the local biomass burning emissions from those that are regionally distributed. Additionally, high-time-resolution data of biomass burning emissions are needed to improve the atmospheric dispersion models of smoke plumes in the atmosphere.

The particle-into-liquid sampler (PILS) was developed for collecting samples of water-soluble compounds in aerosols (Weber et al., 2001). PILS enables the online analysis of the collected samples with several analytical devices, such as ion chromatographs (IC), analyzers for water-soluble organic carbon (WSOC), or liquid wavelength capillary cell and absorbance spectrophotometry (e.g., Orsini et al., 2003; Sullivan et al., 2004; Rastogi et al., 2009; Timonen et al., 2010). Also an application of the online coupling of the PILS with a solid-phase extraction to liquid chromatography-mass spectrometry has been presented for the analysis of organic acids in aerosols (Parshintsev et al., 2010). Recently Sciare et al. (2012) presented a technique where the aerosol sample is collected with the PILS and directly injected to an electrospray ionization source-tandem mass spectrometer (ESI-MS/MS) to measure levoglucosan in real time from ambient air.

The highly time-resolved data of biomass burning emissions can also be gained with aerosol mass spectrometers (AMS) by using the mass fragments specific for biomass burning. Mass-to-charge ratios $(\mathrm{m} / \mathrm{z})$ of 60 and 73 have been shown to be associated with biomass burning (e.g., Alfarra et al., 2007). These mass fragments may originate from levoglucosan and other MAs but also from other sugar compounds that can be from other sources.

In our previous paper (Saarnio et al., 2010b), we presented a HPAEC-MS method for the analysis of MAs from filter samples. In the present study, we combined a PILS with the HPAEC-MS in order to measure levoglucosan in ambient aerosol online with the time resolution of eight minutes. The levoglucosan concentrations measured with the developed PILS-HPAEC-MS method were compared with those measured from concurrently collected filter samples. Moreover, the levoglucosan results were compared with the biomass burning tracer fragments measured with an Aerodyne high-resolution time-of-flight aerosol mass spectrometer (HR-ToF-AMS).

\section{Methods}

\subsection{Site description}

The measurements were conducted between 16 February and 25 March 2011 at the SMEAR III station, an urban background site in Helsinki, Finland $\left(60^{\circ} 12 \mathrm{~N}, 24^{\circ} 57 \mathrm{E}\right.$, $30 \mathrm{~m}$ a.s.l.). The local meteorological data, including air temperature $(T)$, wind speed (WS), and wind direction (WD), were recorded at the same station. The mean daily temperature remains typically below $0{ }^{\circ} \mathrm{C}$ in winter, but warm airflows can raise the daily high above $0^{\circ} \mathrm{C}$ at times. During the measurement campaign, the air temperature ranged between -24 and $6^{\circ} \mathrm{C}$.

About one million inhabitants live in the Helsinki Metropolitan Area, in which about 65000 detached houses exist and approximately $90 \%$ of them have some kind of fireplace. In the urban areas of Helsinki Metropolitan Area, the particles that originate from wood combustion are typically regionally distributed and/or long-range transported because there are only few local wood combustion sources in the urban areas of Helsinki (Saarnio et al., 2012). The main emission sources of $\mathrm{PM}_{1}$ (particles with aerodynamic diameter smaller than $1 \mu \mathrm{m}$ ) in the metropolitan area are long-range transport and traffic throughout the year, smallscale wood combustion at the residential areas with detached houses mainly in the cold season, and secondary organic aerosol (SOA) formation in the warm season (Saarikoski et al., 2008b). In addition, smoke from open-land fires in Russia and Eastern Europe is transported occasionally to the area during the warm season (Saarikoski et al., 2007; Niemi et al., 2009; Saarnio et al., 2010a).

\subsection{Materials}

Levoglucosan (1,6-anhydro- $\beta$-D-glucopyranose; purity 99+ \%; Acrōs Organics, NJ, USA), mannosan (1,6-anhydro$\beta$-D-mannopyranose; purity $99 \%$; Sigma-Aldrich Co., MO, USA), and galactosan (1,6-anhydro- $\beta$-D-galactopyranose; 


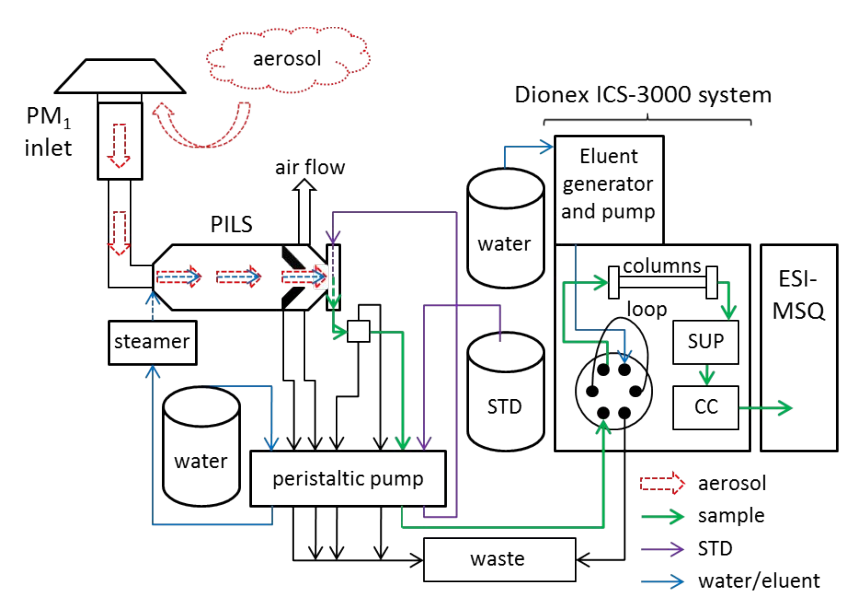

Fig. 1. Schematic representation of the sampling line and the online coupled PILS-HPAEC-MS apparatus. Arrows represent the flow of the aerosol sample and the liquids within the system. STD = standard solution containing internal standard and standard addition of levoglucosan; SUP = suppressor; CC = conductivity cell; ESI$\mathrm{MSQ}=$ quadrupole mass spectrometer with electrospray ionization. The figure is not to scale.

Sigma-Aldrich Co.) were used for the calibration and as standard addition compounds. Methyl- $\beta$-D-arabinopyranoside (purity $99 \%$; Aldrich Chemical Co., WI, USA) was used as an internal standard compound (ISTD). Carbon-13-labeled levoglucosan $\quad\left(1,6\right.$-anhydro- $\beta$-D-[UL- ${ }^{13} \mathrm{C}_{6}$ ]-glucopyranose in dimethyl sulfoxide; $100 \mu \mathrm{g} \mathrm{mL}{ }^{-1}$, purity $98 \%, 1.2 \mathrm{~mL}$ ampoule; Cambridge Isotope Laboratories, Inc., MA, USA) was used for the comparison of ISTD. Deionized water (Milli-Q water; resistivity $18.2 \mathrm{M} \Omega \mathrm{cm}$ at $25^{\circ} \mathrm{C}$, total organic carbon 3-5 $\mu \mathrm{g} \mathrm{L}^{-1}$ ) was produced with a Millipore Gradient A10 water purification system (Merck Millipore, MA, USA), and it was used in standard solutions and as vaporizing water in the PILS, and it was given for eluent generator of the analysis instrument.

Quartz filters (47 mm, Tissuquartz ${ }^{\mathrm{TM}}$, Pall Life Sciences) and polytetrafluoroethylene (PTFE) membrane filter $(47 \mathrm{~mm}$, $3.0 \mu \mathrm{m}$ FS, Fluoropore ${ }^{\mathrm{TM}}$, Millipore) were used for collecting air particulate samples. The samples extracted from the collected filters were filtered through IC Acrodisc ${ }^{\circledR}$ syringe filters (13 mm, $0.45 \mu \mathrm{m}$ Supor ${ }^{\circledR}$ (PES) membrane, Pall Sciences) for the analysis.

\subsection{Set-up for online analysis of levoglucosan}

The online measurement of levoglucosan was conducted between 16 February and 25 March 2011. The measurement campaign was divided into five periods (Periods A-E) with different analytical conditions.

\subsubsection{Sampling with PILS}

PILS enables the online measurement of water-soluble material in aerosol particles (Weber at al., 2001; Orsini et al., 2003). An extensive review of the previously reported PILS campaigns has been presented in Timonen et al. (2010), where the principle of the PILS was also given. The schematic diagram of the sampling system and the analysis apparatus used in the present study is presented in Fig. 1. Fine particles were sampled from ambient air through a sizeselective inlet (Digitel LVS/PM) that removed the particles with an aerodynamic diameter larger than $1 \mu \mathrm{m}$. The sampling line did not include denuders because levoglucosan is in particle phase at ambient temperature (Oja and Suuberg, 1999). The air flow $\left(16.7 \mathrm{~L} \mathrm{~min}^{-1}\right)$ was directed to the PILS, where the particles were grown with saturated water vapor to droplets and impacted onto the impaction plate, which was flushed with a steady stream of a standard solution $\left(130 \mu \mathrm{L} \mathrm{min}{ }^{-1}\right)$. The standard solution contained the internal standard compound and the standard addition of levoglucosan. The effluent, i.e., the sample solution flushed from the impaction plate, was split at a debubbler unit. The flow rate of the effluent that was directed to the sample loop $(50 \mu \mathrm{L})$ of the HPAEC instrument was $70 \mu \mathrm{L} \mathrm{min}^{-1}$ so that the loop was filled in less than one minute. The sample loop volume was tested to be suitable for separation of levoglucosan from two other MAs (Saarnio et al., 2010b). Then the sample was automatically injected into the column for analysis. During the time required for the sample elution and detection (about eight minutes), the sample loop was flushed and filled with the following sample. A minor drawback with the loop timing is that the achieved data are only semicontinuous, and the chromatograms represent less than a one-minute sampling period over the eight-minute analysis period. In this study, most of the sample solution flow was directed to waste. However, it could be directed to other analysis apparatuses, such as ion chromatographs or a carbon analyzer, or it could be collected for offline analysis to gain more information about the sample.

\subsubsection{Determination with HPAEC-MS}

The online determination of levoglucosan was conducted with a high-performance anion-exchange chromatograph coupled to a quadruple mass spectrometer (HPAEC-MS). The HPAEC-MS method for the analysis of MAs was recently developed and validated for laboratory use and it was published by Saarnio et al. (2010b). The analysis instrument was a Dionex ICS-3000 system designed for ion chromatography with Dionex MSQ ${ }^{\mathrm{TM}}$. The used chromatography set-up consisted of a Dionex CarboPac ${ }^{\mathrm{TM}}$ PA10 guard column $(2 \mathrm{~mm}$ i.d. $\times 50 \mathrm{~mm}$ length) and a Dionex CarboPac ${ }^{\mathrm{TM}}$ PA10 analytical column $\left(2 \mathrm{~mm}\right.$ i.d. $\times 250 \mathrm{~mm}$ length), a $2 \mathrm{~mm}$ ASRS $^{\circledR}$ 300 suppressor, a CR-ATC anion trap column, and a EGC II $\mathrm{KOH}$ eluent generator. The ionization was made using the 
electrospray technique (ESI) in the negative mode, and the mass range scanning $(\mathrm{m} / \mathrm{z}, 50-250)$ and selected ion monitoring (SIM) modes were used for the detection. The molecular ions of levoglucosan were monitored with $m / z 161$ and the internal standard with $m / z$ 163. Data were stored and processed with a Dionex Chromeleon ${ }^{\circledR}$ (6.8) system.

The HPAEC-MS equipment was calibrated using eight solutions, with concentrations from 0 to $500 \mathrm{ng} \mathrm{mL}^{-1}$ of levoglucosan and from 0 to $50 \mathrm{ng} \mathrm{mL}^{-1}$ of mannosan and galactosan, made from stock solutions. These solutions contained also the ISTD (the same concentration that was used in the standard solution of PILS; see Sect. 3.1).

In order to get data with a highest possible time resolution, the HPAEC-MS analysis time was chosen to be eight minutes, which was less than in the offline method (15 min) described in Saarnio et al. (2010b). The target analytes are eluted in eight minutes, but there is a possibility that the later eluting monosaccharides (such as glucose) may overlap with the target analytes in the following analysis runs. It was earlier seen that the high ionization probe temperature of MS induces slight dehydration of monosaccharides forming MAs (Saarnio et al., 2010b). However, glucose was not found in the fine-particle samples collected on the filters at the same site in wintertime, and therefore the shorter run time was considered suitable for the PILS-HPAEC-MS method.

\subsubsection{Maintenance procedures}

The operational requirements of the PILS-HPAEC-MS system included maintaining the supply of internal standard and deionized water for the use of the PILS and HPAEC as well as running a calibration standard approximately every other day to verify that the complete analytical system was functioning within acceptable limits. The air flow of the sampler and the liquid flows of the standard solution and the effluent were checked weekly.

\subsection{TEOM}

The mass concentration of $\mathrm{PM}_{1}$ was measured with a tapered element oscillating monitor $\left(\mathrm{TEOM}^{\circledR}\right.$, model 1400ab, Rupprecht \& Pataschnik). An online cyclone (sharp cut cyclone SCC1.829, BGI Inc.) was used to cut off the supermicrometer particles before the TEOM. The time resolution of the TEOM was $30 \mathrm{~min}$. The results of the TEOM were not corrected for the evaporation of semivolatile aerosol compounds.

\subsection{Filter samples}

Concurrently with the PILS-HPAEC-MS measurements, $\mathrm{PM}_{1}$ filter samples were collected and analyzed offline with the HPAEC-MS. The sampling procedure was similar to that presented by Saarnio et al. (2010b). Briefly, the sampling air flow was directed through the four upper stages of a Berner low-pressure impactor to remove the super-micrometer par- ticles and the fraction of $\mathrm{PM}_{1}$ was sampled on a filter. The sampling was conducted by dividing the sample flow into two and using two filter cassette systems in parallel: one with two pre-fired quartz filters one upon the other (front + backup) and the other with a PTFE filter. The sampling duration varied from 18 to $72 \mathrm{~h}$. The flow rate was $40 \mathrm{~L} \mathrm{~min}^{-1}$ for each filter cassette system.

Levoglucosan was analyzed from the quartz filters by punching a $1 \mathrm{~cm}^{2}$ piece from the filter, followed by an extraction with $5 \mathrm{~mL}$ of deionized water (containing the same concentration of internal standard as in the standard solution of the PILS) and filtering through an IC Acrodisc ${ }^{\circledR}$ syringe filter prior to the injection. The offline analysis was conducted with the HPAEC-MS using the same analysis program and apparatus as presented above for the online analyses. Part of the filter samples was analyzed during the maintenance breaks of the online system and the rest after the measurement campaign. The filter samples were stored in a freezer before the analysis. To determine the mass of the sampled $\mathrm{PM}_{1}$, the PTFE filters were weighed before and after the sampling with a Mettler Toledo UMT2 balance (readability of $1 \mu \mathrm{g}$; Mettler Toledo GmbH, Switzerland).

\subsection{HR-ToF-AMS}

The Aerodyne high-resolution time-of-flight aerosol mass spectrometer (Aerodyne Research Inc; DeCarlo et al., 2006) operated at SMEAR III from 22 February to 25 March 2011. HR-ToF-AMS was alternating between $\mathrm{V}$ and $\mathrm{W}$ mode, but due to issues in $\mathrm{W}$ mode only $\mathrm{V}$ mode results were used. The time resolution for the HR-ToF-AMS was six minutes.

Collection efficiency (CE) of 0.5 was used in order to calculate the ambient concentrations of the chemical species from the HR-ToF-AMS data. CE depends on several factors, e.g., particle chemical composition and relative humidity (Middlebrook et al., 2012). Timonen et al. (2010) compared chemical species from the HR-ToF-AMS with the semicontinuous OC/EC, PILS-IC and TEOM results, showing that a $\mathrm{CE}=0.5$ is appropriate for the HR-ToF-AMS data collected in Helsinki in springtime. In this study only the total mass from the HR-ToF-AMS, with a $\mathrm{CE}=0.5$, was compared with the mass concentration from the TEOM. The mass concentration from the HR-ToF-AMS correlated quite well with that from the TEOM $\left(R^{2}=0.79\right)$; however, HR-ToF-AMS mass concentrations were $14 \%$ higher than those from the TEOM.

HR-ToF-AMS data were analyzed with a standard AMS data analysis software (SQUIRREL $1.51 \mathrm{H}$ and PIKA $1.10 \mathrm{H})$. The $m / z$ of 60 and 73 , which are used as tracer mass fractions for biomass burning (Schneider et al., 2006; Alfarra et al., 2007), were obtained from the high-resolution data $\left(m / z 60.021 \quad\left(\mathrm{C}_{2} \mathrm{H}_{4} \mathrm{O}_{2}^{+}\right)\right.$and 73.029 $\left(\mathrm{C}_{3} \mathrm{H}_{5} \mathrm{O}_{2}^{+}\right)$, respectively).

In separate laboratory measurements, the HR-ToF-AMS mass spectrum for a levoglucosan standard was obtained. A standard solution of levoglucosan was prepared by dissolving 


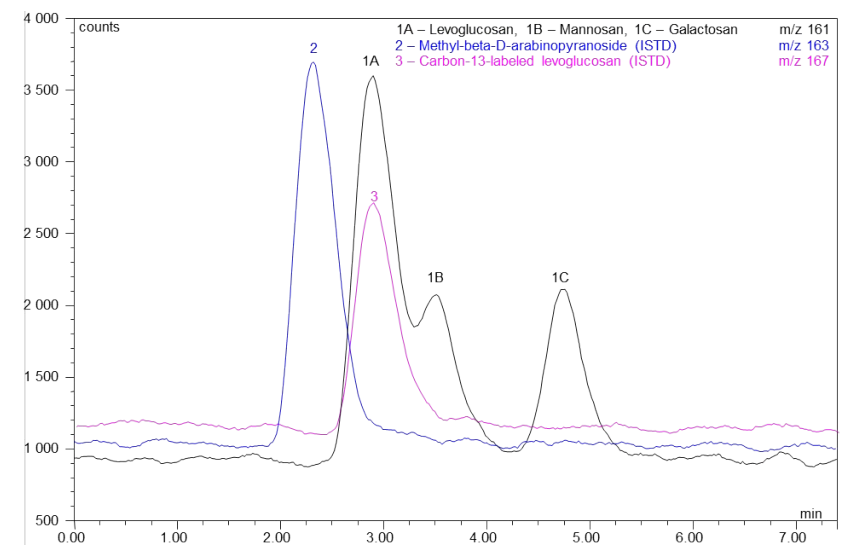

Fig. 2. Chromatogram of the MAs and the two ISTD compounds with the HPAEC-MS.

the solid standard compound into deionized water. The solution was then atomized with a constant output atomizer (TSI Model 3068, St Paul, Minnesota, USA), the aerosol was dried with a diffusion dryer, and a monodisperse aerosol fraction $(300 \mathrm{~nm})$ was selected with a differential mobility analyzer (TSI Model 3080, St Paul, Minnesota, USA). The selected aerosol fraction was then analyzed with the HR-ToF-AMS in order to obtain the ratios of $\mathrm{C}_{2} \mathrm{H}_{4} \mathrm{O}_{2}^{+}$and $\mathrm{C}_{3} \mathrm{H}_{5} \mathrm{O}_{2}^{+}$to levoglucosan concentrations in the HR-ToF-AMS mass spectra.

\section{Results and discussion}

The aim of this study was to develop a fast online method for the determination of levoglucosan in atmospheric aerosols enabling the detection of biomass burning emissions in real time. This study included the development of the analytical method, the results from a month-long campaign and the validation of the results by comparing the online results with filter samples and data from the HR-ToF-AMS.

\subsection{Characteristics of PILS-HPAEC-MS}

\subsubsection{Use of internal standard}

In the PILS methods, dilution of the sample solution in the PILS and the changes in the response of the MS can cause variation in the online determination. The amount of condensed water in PILS depends on the quantity and watersolubility of the particles in the sample air. An ISTD compound is needed to correct for these fluctuations. The concentration of the ISTD is measured when the ISTD solution is prepared and then the concentration of ISTD is analyzed in each PILS sample, and hence the analyte concentration in aerosol can be calculated accurately.

In the present study, the PILS-HPAEC-MS method was developed based on the HPAEC-MS method that was developed for offline analysis of levoglucosan in our previous

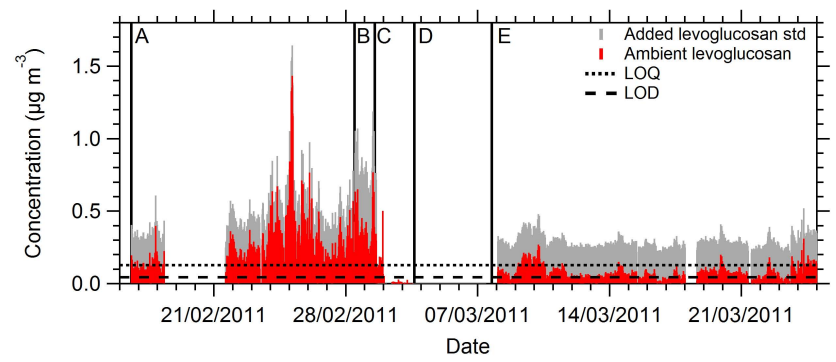

Fig. 3. Ambient levoglucosan concentrations during the campaign and the changes in the analytical conditions. The concentrations of ISTD and standard addition, respectively $\left(\mathrm{ng} \mathrm{mL}^{-1}\right)$ : (A) 50 and 50, (B) 50 and 100, (C) 50 and 0, (D) 100 and 0, (E) 100 and 50.

study (Saarnio et al., 2010b). In that method, levoglucosan${ }^{13} \mathrm{C}_{6}$ was used as ISTD. In the online method, levoglucosan-

${ }^{13} \mathrm{C}_{6}$ was replaced with methyl- $\beta$-D-arabinopyranoside because it has a different retention time from levoglucosan, and therefore it does not cause ion suppression in levoglucosan determination like levoglucosan- ${ }^{13} \mathrm{C}_{6}$. The consumption of ISTD is notable in the PILS-HPAEC-MS method, and therefore methyl- $\beta$-D-arabinopyranoside is also a substantially less expensive option as ISTD than levoglucosan${ }^{13} \mathrm{C}_{6}$. Methyl-arabinopyranosides are structurally related compounds to levoglucosan and they have previously been used as ISTD compounds in the GC-MS analysis for levoglucosan (Pashynska et al., 2002; Hinwood et al., 2008; Fabbri et al., 2009). Figure 2 presents a chromatogram from a standard compound analysis with the HPAEC-MS that shows the differences in retention time of the two ISTD compounds and levoglucosan.

The PILS-HPAEC-MS method was tested with ISTD concentrations of $50 \mathrm{ng} \mathrm{mL}^{-1}$ and $100 \mathrm{ng} \mathrm{mL}^{-1}$ of methyl$\beta$-D-arabinopyranoside. The $50 \mathrm{ng} \mathrm{mL}^{-1}$ concentration was tested first (periods A-C in Fig. 3). During this test period the ambient levoglucosan concentration was relatively high, but there was a lot of variation in the results of levoglucosan and ISTD as well. The higher ISTD concentration $\left(100 \mathrm{ng} \mathrm{mL}^{-1}\right)$ showed better stability of the method (Periods D-E in Fig. 3).

\subsubsection{Determination range}

In the previously published HPAEC-MS method (Saarnio et al., 2010b), the limit of detection (LOD) and the limit of quantification (LOQ) values for levoglucosan were $2 \mathrm{ng} \mathrm{mL}^{-1}$ and $5 \mathrm{ng} \mathrm{mL}^{-1}$, respectively. When the LOD and LOQ values of the HPAEC-MS method were directly calculated from the sampling times of the PILSHPAEC-MS method (the respective LOD and LOQ values for the levoglucosan concentration in the sampled air volume) they were equal to $8.4 \mathrm{ng} \mathrm{m}^{-3}$ and $21 \mathrm{ng} \mathrm{m}^{-3}$, respectively. However, these theoretical values were clearly lower than those observed in ambient air. In the PILS-HPAECMS method, the direct injection of ambient particulate 
sample into the analysis apparatus causes apparently more noise than in the laboratory conditions. Therefore the LOD and LOQ values were estimated to be in the range of 5-10 $\mathrm{ng} \mathrm{mL}^{-1}\left(21-42 \mathrm{ng} \mathrm{m}^{-3}\right.$ in ambient air) and 20$30 \mathrm{ng} \mathrm{mL}^{-1}\left(84-126 \mathrm{ng} \mathrm{m}^{-3}\right)$, respectively.

The linear range of the HPAEC-MS method was from $5 \mathrm{ng} \mathrm{mL}^{-1}$ to about $200 \mathrm{ng} \mathrm{mL}^{-1}$ when methyl- $\beta$-Darabinopyranoside was used as ISTD. Additionally, the determination of the higher levoglucosan concentrations up to about $500 \mathrm{ng} \mathrm{mL}^{-1}$ succeeded using a quadratic calibration curve. The determination range of the PILS-HPAEC-MS method was consequently from LOQ to $500 \mathrm{ng} \mathrm{mL}^{-1}$, i.e., from $84-126 \mathrm{ng} \mathrm{m}^{-3}$ to about $2.1 \mathrm{\mu g} \mathrm{m}^{-3}$. During the measurement campaign, the measured levoglucosan concentrations were within the dynamic range.

\subsubsection{Standard addition method}

The limitation of the method was the determination of levoglucosan of low concentrations. The average wintertime concentration of levoglucosan in the ambient urban background air of Helsinki is relatively low (typically less than $100 \mathrm{ng} \mathrm{m}^{-3}$; Saarnio et al., 2012), that is, on the same concentration level as the estimated LOQ value of the PILSHPAEC-MS method. Therefore a standard addition method was tested to improve the analytical range of the levoglucosan determination.

The levoglucosan standard was added to the flushing solution of the PILS with 0,50 , and $100 \mathrm{ng} \mathrm{mL}^{-1}$ additions. The concentration of flushing standard solution was checked daily by bypassing the PILS and analyzing several replications with the HPAEC-MS. The concentration of levoglucosan in the flushing standard solution was subtracted from the measured concentrations in the ambient samples (Fig. 3). The standard deviation of the standard addition was $16 \%$ with the concentration of $50 \mathrm{ng} \mathrm{mL} \mathrm{m}^{-1}$. The variation of the standard addition caused some additional inaccuracy in the quantification of ambient levoglucosan concentration, but the standard addition method also enabled a wider range of measurement.

It can be seen from Fig. 3 that only during the first half of the measurements (periods $\mathrm{A}$ and $\mathrm{B}$ ) the concentrations of levoglucosan were above the LOQ, and therefore could theoretically be determined without standard addition. When the method was tested without any standard addition (periods $\mathrm{C}$ and $\mathrm{D}$ ), the levoglucosan peak, however, could not be identified in the chromatograms. It is possible that ambient levoglucosan concentrations decreased from periods A-B to periods $\mathrm{C}-\mathrm{D}$ as after the standard addition was applied again (period E), ambient levoglucosan concentrations were notably lower than during period A-B. That can be confirmed by the HR-ToF-AMS data that show very low values for the molecular fragments of biomass burning aerosol $\left(\mathrm{C}_{2} \mathrm{H}_{4} \mathrm{O}_{2}^{+}\right.$ and $\mathrm{C}_{3} \mathrm{H}_{5} \mathrm{O}_{2}^{+}$) during periods $\mathrm{C}-\mathrm{D}$. The comparison of the

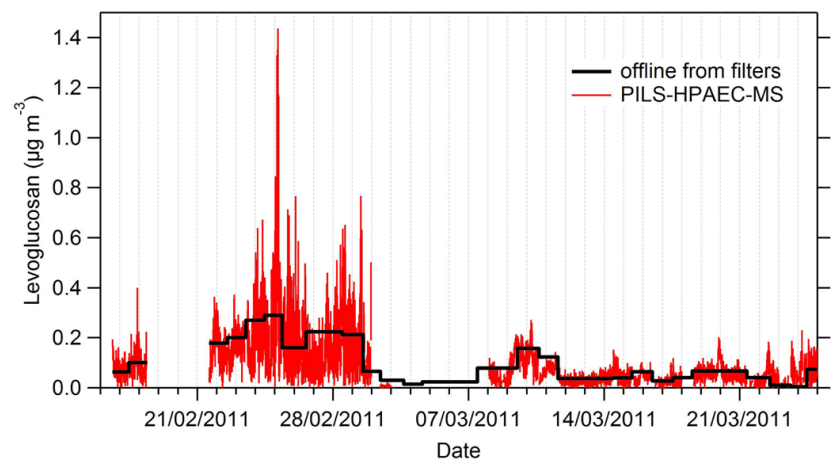

Fig. 4. Time series of levoglucosan measured online with the PILSHPAEC-MS and determined offline from the filter samples with the HPAEC-MS. The PILS-HPAEC-MS measured with a time resolution of $8 \mathrm{~min}$, whereas the sampling duration for the filters varied from 18 to $72 \mathrm{~h}$.

levoglucosan results with the HR-ToF-AMS data will be discussed in detail in Sect. 3.3.

During the measurement campaign, the method was not capable of measuring the isomers of levoglucosan, i.e., mannosan and galactosan, due to their notably lower concentrations in ambient air. In our previous study, levoglucosan contributed on average $86 \%$ to the sum of MAs at the same site (Saarnio et al., 2010b).

\subsection{Comparison with the filter samples}

During the study period, filter samples $(n=23)$ were collected in parallel with the PILS-HPAEC-MS measurements (Fig. 4). With the filter samples the short-term changes in the levoglucosan concentration during the sampling time were lost; for example on 24-25 February, a high-concentration peak of levoglucosan was detected by the PILS-HPAECMS, whereas the levoglucosan concentration in the corresponding filter sample did not differ notably from the adjacent samples (more about this sample is given in Sect. 3.4). Nevertheless, with the filter samples the general decreasing trend of levoglucosan in springtime was observed.

The online levoglucosan data were averaged over the filter sampling periods in order to compare them with the levoglucosan concentrations analyzed from the filters. The leastsquares regression analysis (Fig. 5) showed that the correlation between the online and offline techniques was good $\left(R^{2}=0.903\right)$, but the PILS-HPAEC-MS somewhat underestimated the levoglucosan concentrations compared with those determined from the filter samples. The online levoglucosan concentrations from the PILS-HPAEC-MS were on average $20 \%$ lower than those from the filter samplings. However, the ratio between the PILS-HPAEC-MS and filter results varied; e.g., on 24-25 February the levoglucosan concentration was $21 \%$ lower with the PILS-HPAEC-MS than from the filters, on 26-28 February only $1 \%$ lower and on 10-11 March $41 \%$ lower. A similar difference between the 


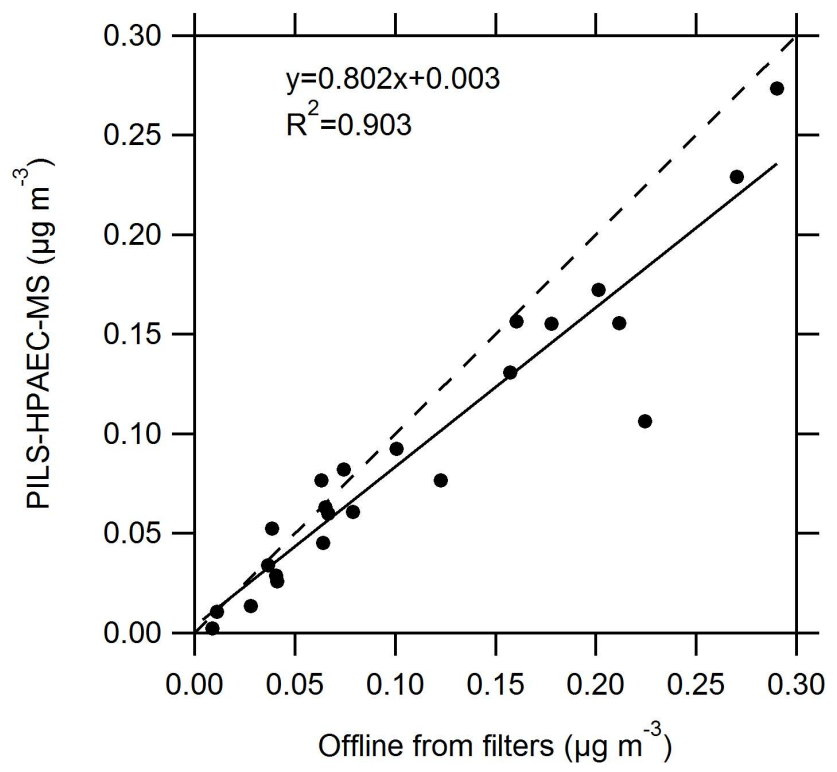

Fig. 5. Comparison of levoglucosan concentrations measured online with the PILS-HPAEC-MS (averaged over the filter sampling times) and the levoglucosan concentrations sampled with filters and analyzed offline with HPAEC-MS. The dotted line represents the $1: 1$ line.

filters and PILS has been detected earlier for the other compounds. Timonen et al. (2011) found that for sulfate the results of the filter samples were on average $18 \%$ higher than the PILS results during a one-year period in Helsinki. An even larger difference was observed for oxalate in Helsinki: Saarikoski (2008) observed that oxalate concentrations were $62 \%$ lower in the PILS than in the filter samples. The smaller results from the PILS-HPAEC-MS method may be due to several causes: (1) typical features of the PILS measurements, e.g., sample loss inside the PILS (Orsini et al., 2003), especially due to the fact that biomass burning particles might contain a significant fraction of black carbon, which is hydrophobic; (2) possible evaporation or degradation of analytes in the PILS; and (3) higher analytical uncertainty for the lower concentrations in the HPAEC-MS.

\subsection{Comparison with the HR-ToF-AMS data}

Levoglucosan concentrations from the PILS-HPAEC-MS method were compared with the biomass burning tracers analyzed from the HR-ToF-AMS data. The concentrations of biomass burning tracers at $m / z 60.021\left(\mathrm{C}_{2} \mathrm{H}_{4} \mathrm{O}_{2}^{+}\right)$and $73.029\left(\mathrm{C}_{3} \mathrm{H}_{5} \mathrm{O}_{2}^{+}\right)$in the HR-ToF-AMS and levoglucosan from the PILS-HPAEC-MS were averaged for $1 \mathrm{~h}$ time resolution for the comparison.

Time series for levoglucosan and AMS tracers are presented in Fig. 6. Both methods detected similar evolution of the concentrations, but the HPAEC-MS had more variation in the concentrations. Most of the high-concentration peaks

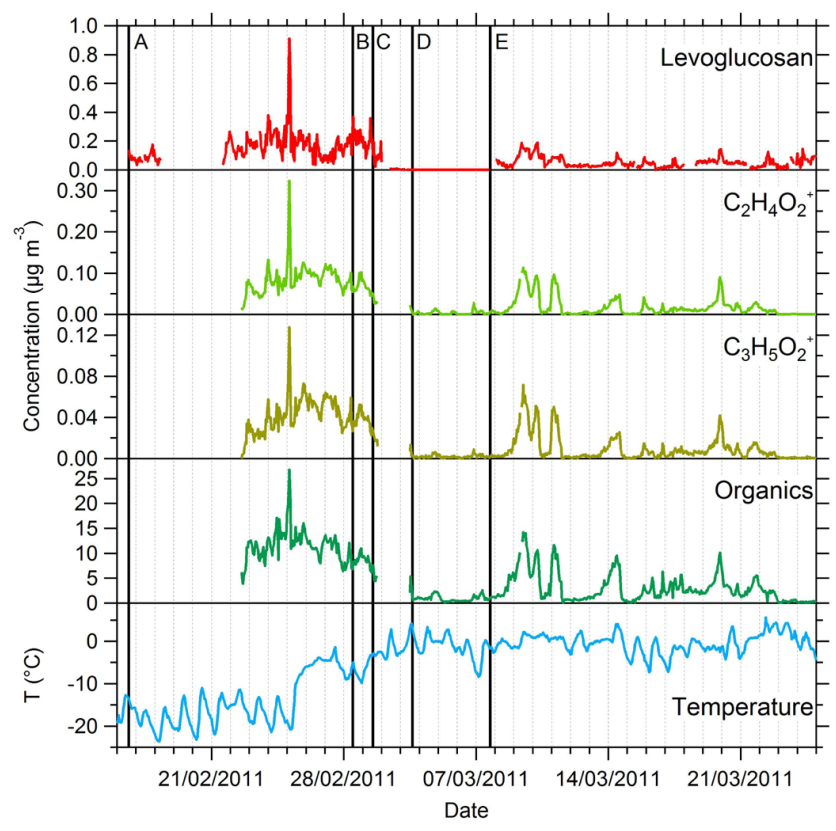

Fig. 6. Online measured levoglucosan (PILS-HPAEC-MS) compared with the time series of $\mathrm{C}_{2} \mathrm{H}_{4} \mathrm{O}_{2}^{+}$and $\mathrm{C}_{3} \mathrm{H}_{5} \mathrm{O}_{2}^{+}$fragments and the sum of organics (HR-ToF-AMS) with the air temperature. All measured values are averaged with $1 \mathrm{~h}$ time resolution. The letters A-E as in Fig. 3.

were observed with both methods, especially the maximum concentration on 25 February, but there were some peaks that were missing in the HR-ToF-AMS data (e.g., 1 March) or in the levoglucosan data (e.g., 27 February and 11 March). Even though both data were averaged to one hour it is possible that HR-ToF-AMS and PILS-HPAEC-MS measured slightly different air; due to the four operating modes in the HR-ToFAMS, the data covered $25 \%$ of the time, whereas the coverage for the PILS-HPAEC-MS data was even smaller, being less than $10 \%$ of the time due to the size of the sample loop.

The correlation between online levoglucosan and $\mathrm{C}_{2} \mathrm{H}_{4} \mathrm{O}_{2}^{+}$ and $\mathrm{C}_{3} \mathrm{H}_{5} \mathrm{O}_{2}^{+}$was moderate $\left(R^{2}=0.63\right.$ and $R^{2}=0.55$, respectively; Fig. 7a, b). There was a lot of variation, especially for the small concentrations, which was possibly caused by the inaccuracy of the standard addition method. The respective correlation coefficients between the concentrations of levoglucosan determined offline from the filter samples and $\mathrm{C}_{2} \mathrm{H}_{4} \mathrm{O}_{2}^{+}$and $\mathrm{C}_{3} \mathrm{H}_{5} \mathrm{O}_{2}^{+}$averaged over the filter sampling times were slightly larger than for the online levoglucosan method $\left(R^{2}=0.83\right.$ and $R^{2}=0.74$, respectively; Fig. $\left.7 \mathrm{c}, \mathrm{d}\right)$.

In order to obtain the ratios of $\mathrm{C}_{2} \mathrm{H}_{4} \mathrm{O}_{2}^{+}$and $\mathrm{C}_{3} \mathrm{H}_{5} \mathrm{O}_{2}^{+}$to levoglucosan concentrations in the HR-ToF-AMS mass spectra, a solution of levoglucosan standard was nebulized and analyzed with the HR-ToF-AMS in the laboratory. $\mathrm{C}_{2} \mathrm{H}_{4} \mathrm{O}_{2}^{+}$ and $\mathrm{C}_{3} \mathrm{H}_{5} \mathrm{O}_{2}^{+}$fragments contributed 10 and $2.6 \%$ to the total mass of levoglucosan, respectively. Based on the ratio of $\mathrm{C}_{2} \mathrm{H}_{4} \mathrm{O}_{2}^{+}$to levoglucosan from the laboratory tests, 


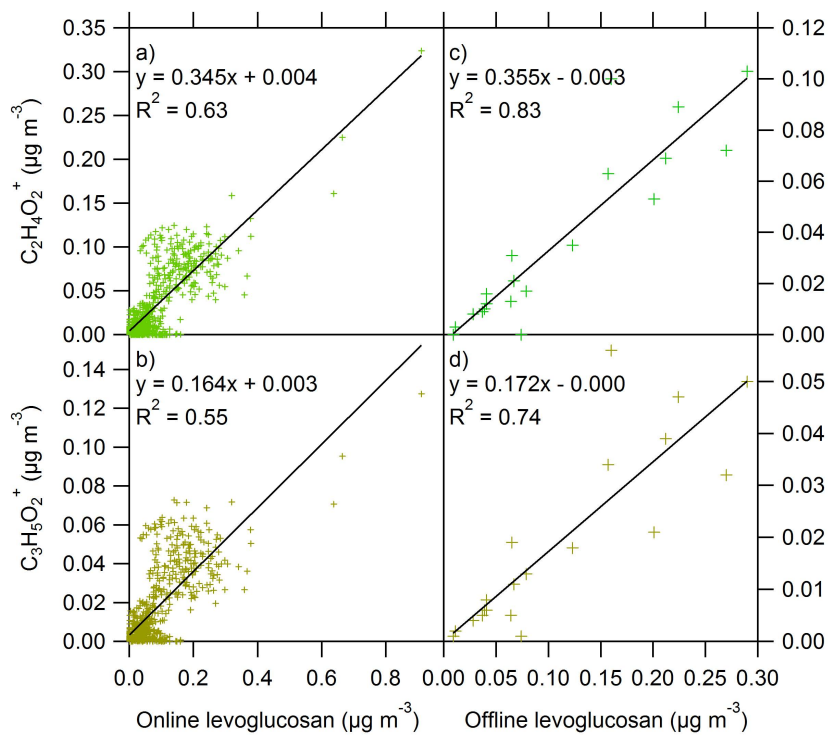

Fig. 7. Comparison of levoglucosan concentrations measured online with the PILS-HPAEC-MS and the biomass burning tracer concentrations measured with the HR-ToF-AMS (the data were averaged with $1 \mathrm{~h}$ time resolution) (a-b); and the comparison of levoglucosan concentrations determined offline from the filter samples with the HPAEC-MS and the biomass burning tracer concentrations measured with the HR-ToF-AMS (the HR-ToF-AMS data were averaged according to the filter sampling times) (c-d).

AMS-levoglucosan equivalent was 3.5 times higher than levoglucosan measured with the PILS-HPAEC-MS. Although the average proportion of levoglucosan is the major anhydrosugar, contributing $86 \%$ to the sum of three anhydrosugars in Helsinki (Saarnio et al., 2010b), it should be noted that also other anhydrosugars can contribute to $\mathrm{C}_{2} \mathrm{H}_{4} \mathrm{O}_{2}^{+}$fragment.

It has been suggested that there are other minor sources for $\mathrm{C}_{2} \mathrm{H}_{4} \mathrm{O}_{2}^{+}$in ambient air. Mohr et al. (2009) found $\mathrm{C}_{2} \mathrm{H}_{4} \mathrm{O}_{2}^{+}$ in meat-cooking aerosol and Aiken et al. (2009) subtracted $0.3 \%$ of organic aerosol mass from the $m / z 60$ mostly due to SOA. In this study there was a small offset for $\mathrm{C}_{2} \mathrm{H}_{4} \mathrm{O}_{2}^{+}$concentration $\left(\sim 4 \mathrm{ng} \mathrm{m}^{-3}\right)$ when it was plotted against the online levoglucosan concentration (Fig. 7a). The background $\mathrm{C}_{2} \mathrm{H}_{4} \mathrm{O}_{2}^{+}$was equal to $0.2 \%$ of organic aerosol, which is lower than suggested in Aiken et al. (2009). That is reasonable as the contributions of other sources for $\mathrm{C}_{2} \mathrm{H}_{4} \mathrm{O}_{2}^{+}$, SOA and meat cooking can be assumed to be small in wintertime Helsinki. When $\mathrm{C}_{2} \mathrm{H}_{4} \mathrm{O}_{2}^{+}$was compared to offline levoglucosan from the filter samples, the offset for $\mathrm{C}_{2} \mathrm{H}_{4} \mathrm{O}_{2}^{+}$was negative (Fig. 7c).

Similar to this study, it has been noticed previously that all $\mathrm{C}_{2} \mathrm{H}_{4} \mathrm{O}_{2}^{+}$fragment in the AMS may not be related to levoglucosan or other anhydrosugar molecules. Lee et al. (2010) calculated an AMS anhydrosugar-equivalent concentration using a multiplying factor of 7.5 for $\mathrm{C}_{2} \mathrm{H}_{4} \mathrm{O}_{2}^{+}$for the estimation of the sum of levoglucosan, mannosan, and galactosan. They found that in the conditions of open biomass burning,

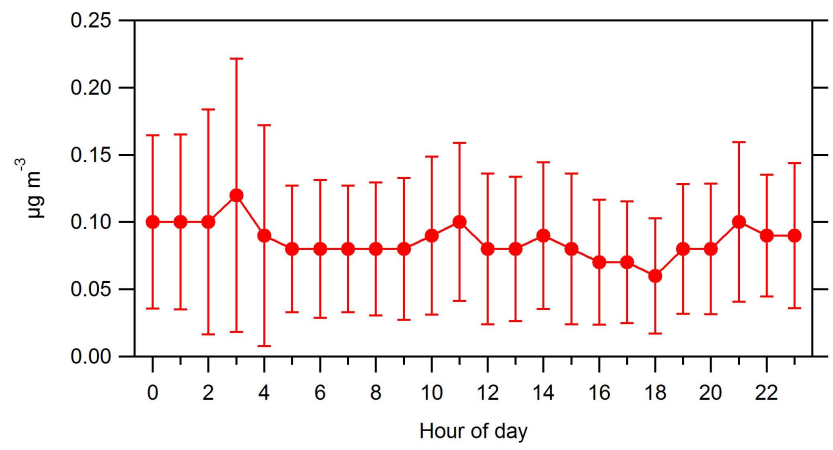

Fig. 8. Average levoglucosan concentration for each hour of day during the campaign. The vertical lines represent one standard deviation.

the sum of three anhydrosugars, determined from filter samples, made up only a fraction of the estimated AMS anhydrosugar equivalent concentration (AMS-equivalent concentration was 8.5 times higher). They explained the difference by other structurally similar compounds in smoke that produce the same fragment (e.g., glucose). Just the opposite behavior was noticed in the ambient measurement in the Po Valley, Italy (Saarikoski et al., 2012). Based on the same fragmentation patterns for anhydrosugars that were used in Lee et al. (2010), only $25 \%$ of the anhydrosugar concentrations measured from the filter samples could be reproduced from the HR-ToF-AMS data in Italy. It was speculated that the lower values were due to the difference in the fragmentation patterns of different instruments.

\subsection{Levoglucosan concentration in atmospheric aerosol}

The average concentration of levoglucosan was $83 \mathrm{ng} \mathrm{m}^{-3}$ during the measurement campaign. That was close to that measured at urban sites in Helsinki during the cold season (83-98 $\mathrm{ng} \mathrm{m}^{-3}$; Saarnio et al., 2012) and slightly higher than the annual average of $64 \mathrm{ng} \mathrm{m}^{-3}$ at the same site (Saarikoski et al., 2008b). The online measured levoglucosan concentration (PILS-HPAEC-MS) was on average $2.3 \%$ of the concentration of organics measured with the HR-ToF-AMS (Fig. 6) and $1.4 \%$ of the $\mathrm{PM}_{1}$ concentration measured with the TEOM (not shown).

There was only a minor difference in the levoglucosan concentrations between the night (18:00-06:00 LT) and day (06:00-18:00 LT). At nighttime the levoglucosan concentration was on average only $8 \%$ higher than in daytime, with the average levoglucosan concentrations (median; range) during the night and day being $86(56 ; 0-1519) \mathrm{ng} \mathrm{m}^{-3}$ and 79 (57; $0-753) \mathrm{ng} \mathrm{m}^{-3}$, respectively. A similar night-day variation has been observed earlier in Helsinki with filter samples (the average nighttime concentration $12 \%$ higher than in daytime during the winter 2008-2009 (Saarnio et al., 2010b) and 8\% in February 2006 (Saarnio et al., 2012)). Similarly, levoglucosan concentration did not seem to have a clear diurnal cycle 


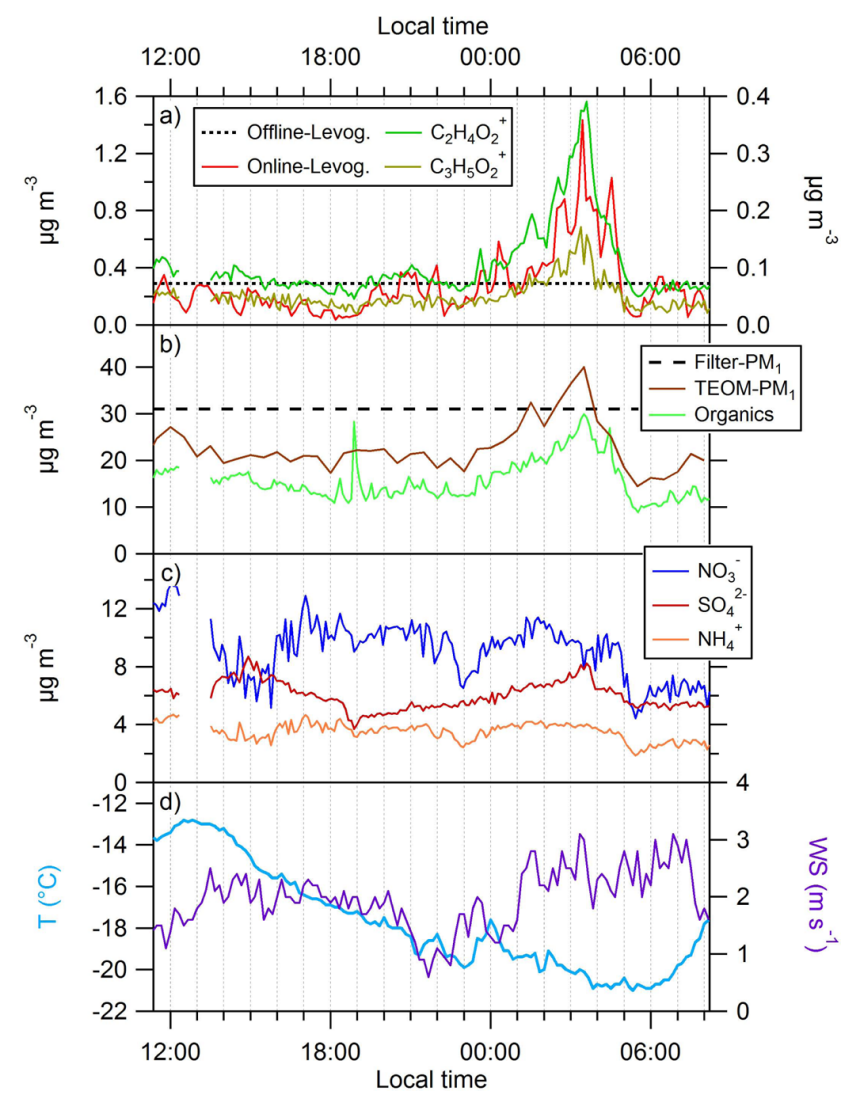

Fig. 9. Concentrations of online levoglucosan with the PILSHPAEC-MS and offline from the filter sample (left axis) and $\mathrm{C}_{2} \mathrm{H}_{4} \mathrm{O}_{2}^{+}$and $\mathrm{C}_{3} \mathrm{H}_{5} \mathrm{O}_{2}^{+}$with the HR-ToF-AMS (right axis) (a); $\mathrm{PM}_{1}$ mass with the TEOM and from the filter sample and organics with the HR-ToF-AMS (b); nitrate, sulfate and ammonium with the HR-ToF-AMS (c); as well as air temperature and wind speed (d) during the filter sampling on 24-25 February 2011.

(Fig. 8), which implies that there are no, or only few, local biomass burning sources. Instead of a clear night-day variation or diurnal cycle, there seemed to be plumes from regional wood combustion sources and transported from Baltic countries and Central Europe that affected the levoglucosan concentrations in Helsinki. Those long-range transported plumes did not have a dependence on the time of the day. These observations support the estimations made in our previous study (Saarnio et al., 2012), in which we estimated that in the urban background of Helsinki the particles from biomass burning are either regionally distributed or longrange transported.

The highest levoglucosan concentration was measured during the night between 24 and 25 February, when the levoglucosan concentration increased temporally up to $1.4 \mu \mathrm{g} \mathrm{m}^{-3}$ (Fig. 9a). The detected plume lasted for about three-and-a-half hours, of which for two hours the levoglucosan concentration was higher than $0.5 \mu \mathrm{g} \mathrm{m}^{-3}$. The concurrent filter sample (from 24 February, 11:22, to 25 Febru- ary, 08:12) was collected for $21 \mathrm{~h}$ and the levoglucosan concentration was $0.29 \mathrm{\mu g} \mathrm{m}^{-3}$. The meteorological data showed that air temperature and wind speed were low during that night (Fig. 9d). The principal wind direction was from eastsoutheast. In that direction there are a few small residential areas with detached houses (3-7 km away from the measurement station). However, it is unlikely that fireplaces would have been used at that time of the night, at least not to a large extent.

The $\mathrm{PM}_{1}$ concentration measured with the TEOM as well as organics measured with the HR-ToF-AMS increased simultaneously with levoglucosan (Fig. 9b). However, the increase was more pronounced for levoglucosan than for $\mathrm{PM}_{1}$ and organics; levoglucosan concentration was $3.2 \%$ of the concentration of organics and $2.7 \%$ of the $\mathrm{PM}_{1}$ concentration during the plume, which were 37 and $88 \%$ higher contributions than the averages for the whole measurement period, respectively. The other main particulate components did not show a behavior similar to biomass burning tracers, although sulfate increased slightly (Fig. 9c), which implies that the reason for the high concentrations was not temperature inversion. Instead, the backward air mass trajectories (HYSPLIT transport and dispersion model, NOAA Air Resources Laboratory; Draxler and Rolph, 2013) showed that the air masses came to Helsinki from Estonia ( $>70 \mathrm{~km}$ away from Helsinki) during that night. Presumably the measured levoglucosan originated mainly from the wood combustion in Estonian households earlier in the evening of 24 February.

\section{Conclusions}

A new application was developed for the online analysis of levoglucosan in atmospheric aerosol in which the sample collection with the PILS was combined with fast analysis by HPAEC-MS. The time resolution of the PILS-HPAEC-MS method was eight minutes. With a standard addition method, the method was shown to be capable of measuring the typical wintertime background concentrations of levoglucosan in Helsinki, Finland.

A fairly good agreement in levoglucosan concentrations determined using the filter and PILS samplings showed that the PILS-HPAEC-MS method was able to measure levoglucosan accurately and that the PILS-HPAEC-MS was a useful tool for measuring the levoglucosan concentrations in ambient fine particles. Short-term changes in the levoglucosan concentration were detected with the PILS-HPAECMS method, whereas that information was lost in the integrating filter samples. The short-term changes in the levoglucosan concentration corresponded to the biomass burning tracers measured with the HR-ToF-AMS. The ratio between levoglucosan and the biomass burning tracers implies that in the urban background air in Helsinki, an important part of the $\mathrm{C}_{2} \mathrm{H}_{4} \mathrm{O}_{2}^{+}$fragment measured by HR-ToF-AMS is caused by levoglucosan and other anhydrosugars. 
Levoglucosan concentrations ranged from LOD to $1.4 \mu \mathrm{g} \mathrm{m}^{-3}$ with an average of $0.083 \mu \mathrm{g} \mathrm{m}^{-3}$ during the measurement campaign. Levoglucosan did not have any clear diurnal trend. Concentrations were slightly larger at nighttime than in daytime, but the difference was insignificant. That was expected as there were no local biomass burning sources near the measurement station. The largest concentration peak was observed on 25 February, when biomass burning smoke from Estonia was transported to Helsinki.

Acknowledgements. The study was funded by the Academy of Finland (contract nos. 122870 and 124387) and by the Finnish Funding Agency for Technology and Innovation (contract no. 40209/08).

Edited by: W. Maenhaut

\section{References}

Aiken, A. C., Salcedo, D., Cubison, M. J., Huffman, J. A., DeCarlo, P. F., Ulbrich, I. M., Docherty, K. S., Sueper, D., Kimmel, J. R., Worsnop, D. R., Trimborn, A., Northway, M., Stone, E. A., Schauer, J. J., Volkamer, R. M., Fortner, E., de Foy, B., Wang, J., Laskin, A., Shutthanandan, V., Zheng, J., Zhang, R., Gaffney, J., Marley, N. A., Paredes-Miranda, G., Arnott, W. P., Molina, L. T., Sosa, G., and Jimenez, J. L.: Mexico City aerosol analysis during MILAGRO using high resolution aerosol mass spectrometry at the urban supersite (T0) - Part 1: Fine particle composition and organic source apportionment, Atmos. Chem. Phys., 9, 6633-6653, doi:10.5194/acp-9-6633-2009, 2009.

Alfarra, M. R., Prevot, A. S. H., Szidat, S., Sandradewi, J., Weimer, S., Lanz, V. A., Schreiber, D., Mohr, M., and Baltensberger, U.: Identification of the mass spectral signature of organic aerosols from wood burning emissions, Environ. Sci. Technol., 41, 57705777, 2007.

Boman, B. C., Forsberg, A. B., and Järvholm, B. G.: Adverse health effects from air pollution in relation to residential wood combustion in modern society, Scand. J. Work Environ. Health, 29, 251-260, 2003.

DeCarlo, P. F., Kimmel, J. R., Trimborn, A., Northway, M., Jayne, J. T., Aiken, A. C., Gonin, M., Fuhrer, K., Horvath, T., Docherty, K. S., Worsnop, D. R., and Jimenez, J. L.: Field-deployable, high-resolution, time-of-flight aerosol mass spectrometer, Anal. Chem., 78, 8281-8289, 2006.

Draxler, R. R. and Rolph, G. D.: HYSPLIT (HYbrid Single-Particle Lagrangian Integrated Trajectory) Model access via NOAA ARL READY Website (http://ready.arl.noaa.gov/HYSPLIT. php), NOAA Air Resources Laboratory, Silver Spring, MD, 2013.

Dye, C. and Yttri, K. E.: Determination of monosaccharide anhydrides in atmospheric aerosols by use of high-performance liquid chromatography combined with high-resolution mass spectrometry, Anal. Chem., 77, 1853-1858, 2005.

Engling, G., Carrico, C. M., Kreidenweis, S. M., Collett Jr., J. L., Day, D. E., Malm, W. C., Lincoln, E., Hao, W. M., Iinuma, Y., and Herrmann, H.: Determination of levoglucosan in biomass combustion aerosol by high-performance anion-exchange chro- matography with pulsed amperometric detection, Atmos. Environ., 40, S299-S311, 2006.

Fabbri, D., Torri, C., Simoneit, B. R. T., Marynowski, L., Rushdi, A. I., and Fabiańska, M. J.: Levoglucosan and other cellulose and lignin markers in emissions from burning of Miocene lignites, Atmos. Environ., 43, 2286-2295, 2009.

Fraser, M. P. and Lakshmanan, K.: Using levoglucosan as a molecular marker for the long-range transport of biomass combustion aerosols, Environ. Sci. Technol., 34, 4560-4564, 2000.

Gilardoni, S., Vignati, E., Cavalli, F., Putaud, J. P., Larsen, B. R., Karl, M., Stenström, K., Genberg, J., Henne, S., and Dentener, F.: Better constraints on sources of carbonaceous aerosols using a combined ${ }^{14} \mathrm{C}$ - macro tracer analysis in a European rural background site, Atmos. Chem. Phys., 11, 5685-5700, doi:10.5194/acp-11-5685-2011, 2011.

Hennigan, C. J., Sullivan, A. P., Collett, J. L. Jr., and Robinson, A. L.: Levoglucosan stability in biomass burning particles exposed to hydroxyl radicals, Geophys. Res. Lett., 37, L09806, doi:10.1029/2010GL043088, 2010.

Hinwood, A. L., Trout, M., Murby, J., Barton, C., and Symons, B.: Assessing urinary levoglucosan and methoxyphenols as biomarkers for use in woodsmoke exposure studies, Sci. Total Environ., 402, 139-146, 2008.

Hoffmann, D., Tilgner, A., Inuma, Y., and Herrmann, H.: Atmospheric stability of levoglucosan: a detailed laboratory and modelling study, Environ. Sci. Technol., 44, 694-699, 2010.

Iinuma, Y., Engling, G., Puxbaum, H., and Herrmann, H.: A highly resolved anion-exchange chromatographic method for determination of saccharic tracers for biomass combustion and primary bio-particles in atmospheric aerosol, Atmos. Environ., 44, 13671371, 2009.

Lee, T., Sullivan, A. P., Mack, L., Jimenez, J. L., Kreidenweis, S. M. Onasch, T. B., Worsnop, D. R., Malm, W., Wold, C. E., Hao, W. M., and Collett, J. L., Jr.: Chemical smoke marker emissions during flaming and smoldering phases of laboratory open burning of wildland fuels, Aerosol Sci. Technol., 44, i-v, doi:10.1080/02786826.2010.499884, 2010.

Middlebrook, A. M., Bahreini, R., Jimenez, J. L., and Canagaratna, M. R.: Evaluation of composition-dependent collection efficiencies for the Aerodyne Aerosol Mass Spectrometer using field data, Aerosol Sci. Technol., 46, 258-271, 2012.

Mohr, C., Huffman, J. A., Cubison, M. J., Aiken, A. C., Docherty, K. S., Kimmel, J. R., Ulbrich, I. M., Hannigan, M., and Jimenez, J. L.: Characterization of primary organic aerosol emissions from meat cooking, trash burning, and motor vehicles with highresolution aerosol mass spectrometry and comparison with ambient and chamber observations, Environ. Sci. Technol., 43, 24432449, 2009.

Naeher, L. P., Brauer, M., Lipsett, M., Zelikoff, J. T., Simpson, C. D., Koenig, J. Q., and Smith, K. R.: Woodsmoke health effects: A review, Inhal. Toxicol., 19, 67-106, 2007.

Niemi, J. V., Saarikoski, S., Aurela, M., Tervahattu, H., Hillamo, R., Westphal, D. L., Aarnio, P., Koskentalo, T., Makkonen, U., Vehkamäki, H., and Kulmala, M.: Long-range transport episodes of fine particles in southern Finland during 1999-2007, Atmos. Environ., 43, 1255-1264, 2009.

Oja, V. and Suuberg, E. M.: Vapor pressures and enthalpies of sublimation of D-glucose, D-xylose, cellobiose, and levoglucosan, J. Chem. Eng. Data, 44, 26-29, 1999. 
Orsini, D. A., Ma, Y., Sullivan, A., Sierau, B., Baumann, K., and Weber, R. J.: Refinements to the particle-into-liquid sampler (PILS) for ground and airborne measurements of water-soluble aerosol composition, Atmos. Environ., 37, 1243-1259, 2003.

Parshintsev, J., Kivilompolo, M., Ruiz-Jimenez, J., Hartonen, K., Kulmala, M., and Riekkola, M.-L.: Particle-into-liquid sampler on-line coupled with solid-phase extraction-liquid chromatography-mass spectrometry for the determination of organic acids in atmospheric aerosols, J. Chromatogr. A, 1217, 5427-5433, 2010.

Pashynska, V., Vermeylen, R., Vas, G., Maenhaut, W., and Claeys, M.: Development of a gas chromatographic/ion trap mass spectrometric method for the determination of levoglucosan and saccharidic compounds in atmospheric aerosols. Application to urban aerosols, J. Mass Spectrom., 37, 1249-1257, 2002.

Piot, C., Jaffrezo, J.-L., Cozic, J., Pissot, N., El Haddad, I., Marchand, N., and Besombes, J.-L.: Quantification of levoglucosan and its isomers by High Performance Liquid Chromatography Electrospray Ionization tandem Mass Spectrometry and its applications to atmospheric and soil samples, Atmos. Meas. Tech., 5, 141-148, doi:10.5194/amt-5-141-2012, 2012.

Ramanathan, V., Crutzen, P. J., Kiehl, J. T., and Rosenfeld, D.: Aerosols, climate, and the hydrological cycle, Science, 294, 2119-2124, 2001.

Rastogi, N., Oakes, M. M., Schauer J. J., Shafer, M. M., Majestic, B. J., and Weber, R. J.: New technique for online measurement of water-soluble Fe(II) in atmospheric aerosols, Environ. Sci. Technol., 43, 2425-2430, 2009.

Saarikoski, S.: Chemical Mass Closure and Source-Specific Composition of Atmospheric Particles. PhD Thesis. Finnish Meteorological Institute Contributions, 74, 182 p., 2008.

Saarikoski, S., Sillanpää, M., Sofiev, M., Timonen, H., Saarnio, K., Teinilä, K., Karppinen, A., Kukkonen, J., and Hillamo, R.: Chemical composition of aerosols during a major biomass burning episode over northern Europe in spring 2006: Experimental and modelling assessments, Atmos. Environ., 41, 3577-3589, 2007.

Saarikoski, S. K., Sillanpää, M. K., Saarnio, K. M., Hillamo, R. E., Pennanen, A. S., and Salonen, R. O.: Impact of biomass combustion on urban fine particulate matter in central and northern Europe, Water Air Soil Poll., 191, 265-277, 2008a.

Saarikoski, S., Timonen, H., Saarnio, K., Aurela, M., Järvi, L., Keronen, P., Kerminen, V.-M., and Hillamo, R.: Sources of organic carbon in fine particulate matter in northern European urban air, Atmos. Chem. Phys., 8, 6281-6295, doi:10.5194/acp-86281-2008, 2008b.

Saarikoski, S., Carbone, S., Decesari, S., Giulianelli, L., Angelini, F., Canagaratna, M., Ng, N. L., Trimborn, A., Facchini, M. C., Fuzzi S., Hillamo, R., and Worsnop, D.: Chemical characterization of springtime submicrometer aerosol in Po Valley, Italy, Atmos. Chem. Phys., 12, 8401-8421, doi:10.5194/acp-12-84012012, 2012.

Saarnio, K., Aurela, M., Timonen, H., Saarikoski, S., Teinilä, K., Mäkelä, T., Sofiev, M., Koskinen, J., Aalto, P. P., Kulmala, M., Kukkonen, J., and Hillamo, R.: Chemical composition of fine particles in fresh smoke plumes from boreal wild-land fires in Europe, Sci. Total Environ., 408, 2527-2542, 2010 a.

Saarnio, K., Teinilä, K., Aurela, M., Timonen, H., and Hillamo, R.: High-performance anion-exchange chromatography-mass spec- trometry method for determination of levoglucosan, mannosan, and galactosan in atmospheric fine particulate matter, Anal. Bioanal. Chem., 398, 2253-2264, 2010 b.

Saarnio, K., Niemi, J. V., Saarikoski, S., Aurela, M., Timonen, H., Teinilä, K., Myllynen, M., Frey, A., Lamberg, H., Jokiniemi, J., and Hillamo, R.: Using monosaccharide anhydrides to estimate the impact of wood combustion on fine particles in the Helsinki Metropolitan Area, Boreal Env. Res., 17, 163-183, 2012.

Schkolnik, G. and Rudich, Y.: Detection and quantification of levoglucosan in atmospheric aerosols: A review, Anal. Bioanal. Chem., 385, 26-33, 2006.

Schneider, J., Weimer, S., Drewnick, F., Borrmann, S., Helas, G., Gwaze, P., Schmid, O., Andreae, M. O., and Kirchner, U.: Mass spectrometric analysis and aerodynamic properties of various types of combustion-related particles, Int. J. Mass Spectrom., 258, 37-49, 2006.

Schreuder, A. B., Larson, T. V., Sheppard, L., and Claiborn, C. S.: Ambient woodsmoke and associated respiratory emergency department visits in Spokane, Washington, Int. J. Occup. Environ. Health, 12, 147-153, 2006.

Sciare, J., Bonnaire, N., Mocnik, G., Nicolas, J., Petit, J. E., Bressi, M., Sarda-Estève, R., and Drinovic, L.: Real-time measurements of levoglucosan in fine aerosols (PM2.5) in the region of Paris (France), Geophys. Res. Abstracts, 14, EGU2012-1560, 2012.

Seinfeld, J. H. and Pandis, S. N.: Atmospheric Chemistry and Physics: From Air Pollution to Climate Change, 2nd Edn., John Wiley \& Sons, New Jersey, 2006.

Simoneit, B. R. T.: Biomass burning - a review of organic tracers for smoke from incomplete combustion, Appl. Geochem., 17, 129162, 2002.

Sullivan, A. P., Weber, R. J., Clements, A. L., Turner, J. R., Bae, M. S., and Schauer, J. J.: A method for on-line measurement of water-soluble organic carbon in ambient aerosol particles: Results from an urban site, Geophys. Res. Lett., 31, L13105, doi:10.1029/2004GL019681, 2004.

Timonen, H., Aurela, M., Carbone, S., Saarnio, K., Saarikoski, S., Mäkelä, T., Kulmala, M., Kerminen, V.-M., Worsnop, D. R., and Hillamo, R.: High time-resolution chemical characterization of the water-soluble fraction of ambient aerosol with PILS-TOC-IC and AMS, Atmos. Meas. Tech., 3, 1063-1074, doi:10.5194/amt3-1063-2010, 2010.

Timonen, H., Aurela, M., Saarnio, K., Frey, A., Saarikoski, S., Teinilä, K., Kulmala, M., and Hillamo, R.: Monitoring of inorganic ions, carbonaceous matter and mass in ambient aerosol particles with online and offline methods, Atmos. Meas. Tech. Discuss., 4, 6577-6614, doi:10.5194/amtd-4-6577-2011, 2011.

Weber, R. J., Orsini, D., Daun, Y., Lee, Y.-N., Klotz, P. J., and Brechtel, F.: A particle-into-liquid collector for rapid measurement of aerosol bulk chemical composition, Aerosol Sci. Technol., 35, 718-727, 2001.

Yttri, K. E., Dye, C., Slørdal, L. H., and Braathen O.-A.: Quantification of monosaccharide anhydrides by liquid chromatography combined with mass spectrometry: application to aerosol samples from an urban and a suburban site influences by small-scale wood burning, J. Air Waste Manage. Assoc., 55, 1169-1177, 2005. 